How to cite: Özbakır G.Ö., Alişiroğlu D.G., Nutritional Physiology and Metabolism of Honey Bees, J. Anim. Prod., 2019, 60 (1): 67-74, DOI: 10.29185 / hayuretim.523081

\section{Review}

(Derleme)

Gonca ÖZMEN ÖZBAKIR1 $10000-0003-1695-4012$ Duygu Gülru ALIŞiROĞLU2@ 0000-0002-2395-7927

${ }^{1}$ Harran Üniversitesi, Ziraat Fakültesi Zootekni

Bölümü, Şanlıurfa, Türkiye

2 Harran Üniversitesi, Fen Bilimleri Enstitüsü,

Zootekni Anabilim Dalı, Şanlıurfa, Türkiye

Corresponding author: gozmenozbakr@harran.edu.tr

\section{Anahtar Kelimeler:}

Bal arısı, bal arısı beslenmesi, sindirim, karbonhidratlar, proteinler

\section{Keywords:}

Honey bee, honey bee nutrition, digestion, carbohydrates, proteins

\title{
Bal Arılarında Beslenme Fizyolojisi ve Metabolizması
}

\author{
Nutritional Physiology and Metabolism of Honey Bees
}

Alınış (Received): 06.02.2019 Kabul tarihi (Accepted): 20.05.2019

\section{öz}

Bal arılarında beslenme; koloni düzeyinde, bireysel ve yavruların beslenmesi olmak üzere üç farklı aşamada irdelenmekte, nektar, karbonhidratça zengin böcek salgıları, polen, arı sütü ve su bal arılarının temel besin kaynaklarını oluşturmaktadır. Polen toplama daha çok koloninin ihtiyacı ile doğru orantılı iken, nektar toplama faaliyeti tarlacı işçi arı mevcuduna, mevsime ve floraya bağlıdır. Su, yavru besininde kullanılmak üzere ve yavru alanı sıcaklığının ayarlanmasında önemli role sahiptir. Bal arılarında fizyolojik yaşa bağlı iş bölümü; besin toplama, depolama, yavru ve ergin bireylerin beslenmesinde de özelleşme ortaya koymuştur. Besin miktarı ve kalitesi koloni yaşamının devamlılığını, hastalık ve zararlılara karşı savunmayı doğrudan etkilemekte, bununla birlikte koloni populasyonun demografik yapısı da toplanan ve depolanan besin miktarını belirlemektedir. Bal arılarının temel karbonhidrat kaynağı nektar, protein kaynağı ise polen ve arı sütüdür. Bu çalışmada bal arılarının bireysel ve koloni düzeyinde büyüme, gelişme ve üreme gereksinimlerinde beslenme fizyolojisi yanı sıra protein ve karbonhidrat metabolizması ile ilgili bilgilerin derlenmesi amaçlanmıştır.

\begin{abstract}
Nutrition in honey bees is studied at three different stages; colony, individuals and broods. Nectar, honeydew (insect secretions with carbohydrate rich), pollen, royal jelly and water are the main food sources of honey bees. While pollen collection is more directly proportional to the needs of the colony, nectar harvesting depends on the foragers, season and flora. Water has an important role for brood's food and to adjust the temperature of the brood area. The physiological age-related division of labor in honey bees has also show a specialization in food collection, storage, feeding of broods and adults. The amount and quality of foods directly affect the continuity of colony life, defense against diseases and pests, but the demographic structure of the colony population also determines the amount of foods collected and stored. The main carbohydrate source of honey bees is nectar and protein source is pollen and royal jelly. The aim of this study is to review nutritional physiology in the growth, development and reproductive requirements of honey bees at individuals and colony level. In addition, it is aimed to compile information about protein and carbohydrate metabolism.
\end{abstract}

\section{Giriş}

Süperorganizma olarak adlandırılan bal arıları; koloni halinde yaşayan, ekolojik, evrimsel ve ekonomik öneme sahip olan sosyal böceklerdir (Seeley, 1989; O'Toole ve Raw, 1991). Tipik bir bal arısı kolonisi üremeden sorumlu bir ana arı, kovan içi ve kovan dışı görevleri yerine getiren işçi arılar, erkek arılar, larva ve pupa döneminde bulunan yavrulardan oluşmaktadır. Fizyolojik ve morfolojik özellikleri bakımından farklı bu koloni bireylerinin, gelişme dönem ve görevlerine göre nitelik ve nicelik olarak farklılaşan beslenme gereksinimleri bulunmaktadır. Diğer canlılarda olduğu gibi bal arıları da üreme, büyüme, gelişme kısacası yaşamsal faaliyetleri yerine getirmek için diyetlerinde karbonhidrat, protein, yağ, vitamin, mineral maddeler, fitosteroller ve suya ihtiyaç duymaktadır. Çiçek nektarı ve böcek salgıları bal arıları için temel enerji kaynağı olup uçuş, termoregülasyon, balmumu salgılamada kullanılırken, polen ise proteinler, yağlar, steroller ve mikrobesin elementlerinin temel kaynağıdır.

Ergin olarak petek gözlerden çıkan genç işçi arılar; temizlik, larva bakım ve besleme, besin depolama, ana arı bakımı gibi kovan içi görevlerde yer alırken, nektar, polen, propolis ve su toplama görevi ise tarlacı işçi 
arılar tarafından yerine getirilmektedir (Winston, 1987). Normal bir kolonide bir işçi arı kovan dışı faaliyetleri ömrünün son iki-üç haftasında gerçekleştirmekte, ancak işçi arılar arasında görev dağılımı üzerine genetik ve çevresel faktörlerin etkisi bulunmaktadır. Koloninin genetik yapısı (özellikle alt aile kompozisyonu), genç işçi arılar arasında olduğu gibi tarlacı işçi arılar arasında da iş bölümünü etkilemektedir (Robinson ve Page, 1989). Ergin işçi arılar koloninin karbonhidrat ve protein gereksinim ve ihtiyacına göre besin arama ya da yavru bakım stratejilerini uyarlayabilirler. Kolonideki larva ve ergin bireyler koloninin gıda stokuna büyük ölçüde bağımlıdırlar. Bal arıları etkin ve başarılı kuluçka üretimi sağlamak için, koloni içi koşullarını (homeostasis) hassas bir şekilde kontrol ederler ve bakıcı görevleri için (teftiş, temizlik, besleme) çok çaba harcayarak yavru büyümesini desteklerler. Genellikle, koloni içerisinde depolanmış büyük miktarda bal, bununla birlikte daha az miktarda polen bulunmaktadır. Bu polen, koloninin ana protein kaynağı olduğundan ve kitlesel yavru üretiminin güçlü bir şekilde bu proteinlere bağlı olması nedeniyle, koloninin polen depolarını yeterli şekilde düzenlemesine özel bir gereksinim vardır (Schmickl ve Crailsheim, 2004).

Doğal ortamlarında yaşayan ve kolonilerde sahiplenilen bal arılarını etkileyen ve bal arısı ölümlerine neden olan mevcut sorunlar, genellikle yetersiz beslenme ile diğer stres faktörleri arasındaki etkileşime atfedilmektedir (Wright ve ark., 2018). Bu çalışmada; zirai, ekolojik ve ekonomik getirileri açısından önemli yere sahip olan bal arılarının sindirim sistemi anatomisi ve fizyolojisi ve temel besin gereksinimleri ile ilgili bilgilerin derlenmesi amaçlanmıştır.

\section{SINDIRIM SISTEMI}

Bal arılarında sindirim sistemi ağızdan başlayarak anüse kadar uzanan, farklı bölgelerinde farklı amaçlar için özelleşmiş bölgelere sahip tüp şeklinde bir kanaldır. Tüm hayvanların embriyolarında sindirim sisteminin kökeni ve erken gelişimi bir noktaya kadar benzerdir. Böceklerde sindirim kanalı embriyo döneminde üç ayrı kısımdan oluşmaya başlar. Yumurta sarısı kalıntıları etrafında, vücudun orta kısmında mesenteron (embriyonik mide) oluşur, ön ve arka kısımda ağız ve anüsü oluşturacak küçük çukurlar meydana gelir, çukurlar derinleştikçe tüpsel iç büyümeler sırasıyla ön bağırsak (stomedeum) ve arka bağırsak (proctedeum) haline gelir. Bu iki kısımın iç uzantıları mesenterona kadar ulaşır sonuçta sürekli bir kanal oluşur. Ön bağırsak ve arka bağırsak, aslında hayvanlarda dış derinin bir devamı olan epitelyum ile kaplıdır ve yüzeyinde sert kütikül oluşturabilme özelliğini korur. Arka bağırsağın iç ucundan daha da dar şekilde içeri doğru büyümüş, memelilerdeki böbrek gibi görev yapan malpigi tüpleri oluşmaktadır. Larva, son besinini alarak pupa dönemine yaklaşıp orta bağırsakta biriken dışkılar atılana kadar, arka bağırsak orta bağırsak ile birleşmez. Ergin arılarda, ön bağırsak; ağız boşluğu, yemek borusu ve bal midesini, orta bağırsak; mideyi (ventrikülüs), arka bağırsak kısmı ise kalın bağırsak ve anüs ile son bulan ince bağırsağı oluşturmaktadır. Bal midesi histolojik olarak yemek borusu ile aynı epitel dokuya sahip olup ana arı ve erkek arılarda da bulunmakla birlikte en gelişmiş hali işçi arılarda görülmektedir. Bal arılarında sindirim sistemi temel olarak abdomende konumlanmış ve uzun bir yemek borusu ile ağıza bağlanmıştır. Yemek borusunun arka ucu ile bağlantılı olan bal midesi genişleyebilen bir formda olup, koloniye nektar veya su taşımada, aynı zamanda uçuşa çıkan işçi arıların uçuş kasları için gerekli olan enerjinin sağlanmasında karbonhidrat depolama görevi bulunmaktadır. Bal midesinin son kısmında bulunan proventriküler valf, sıvı besinlerin mideye geçişine engel olmaktadır. Polen taneleri ise bal midesindeki sıvılardan filtre edilerek sindirim ve emilimin olacağı mideye gönderilmektedir. Polen kabuğu, yağ kürecikleri, ölü mide hücrelerini içeren katı atıklar doğrudan ince bağırsak ve rektuma gönderilirken, nitrojenli sıvı atıklar malpigi tüpleri tarafından kan sıvısından emilir ve boşaltım için ince bağırsağa gönderilir. Rektum, kışın atık malzemelerin tutulabilmesi için önemli ölçüde genişleyebilen bir formdadır (Snodgrass, 1910; Dade, 1962; Winston, 1987).

Böceklerin ana biyosentez ve besin depolama organı olan, yağ doku (fat body), böceklerin yaşamının her aşamasında kritik öneme sahiptir. Holometabolous böceklerin metamorfozları sırasında, neredeyse tüm organlar ve dokular değişir ve yetişkinlere özgü proteinler eksprese edilirken, larva ve pupaya özgü proteinlerin üretimi sonlandırılır (Haunerland ve Shirk 1995). Bal arısı abdomeninin dorsal ve ventral kısımlarında gıda rezervlerinin depolanması için krem renkli hücreler olarak bulunan yağ doku; temel olarak, trakeal dokuya sahip ince loblarla gevşek şekilde düzenlenmiş, abdomen duvarına yayılan ince hücre katmanlarından oluşur. $\mathrm{Bu}$ hücreler poleninin sindirilmesi ile bir gliko-lipo-protein olan vitellogenin sentezleyerek yağ dokuda rezerv gıda maddesi olarak depolarlar. Yağ dokunun gelişimi ergin çıkıştan sonra işçi arıların yeterli miktarda ve kalitede protein (polen) 
tüketmelerine bağlıdır. Benzer şekilde sonbaharda polen tüketimiyle kışlayan işçi arılar iyi gelişmiş hipofarenjeal bezlere ve yağ dokuya sahiptirler (Snodgrass, 1910; Dade, 1962; Winston, 1987).

Sindirim sisteminde özellikle mide ve bağırsakta yaşayan mikroorganizmalar çok mideliler (ruminantlar) ve insanlarda sindirime önemli katkılarda bulunmaktadır. Bal arısı sindirim sisteminde de özellikle son yıllarda yapılmış araştırmalarda bu mikroorganizmaların işlev ve etkileri üzerine yoğunlaşılmış beslenme, büyüme ve gelişme ve bal arısı sağlığı ile ilişkileri incelenmiştir.

Bal arılarının özel bağırsak mikrobiyal topluluğu, her ikisi de çoğunlukla konakçı tarafından uyarlanmış, fakültatif olarak anaerobik ve mikroaerofilik bakterilerden oluştuğu için memeli mikrobiyotasına benzemektedir. Bununla birlikte, arı bağırsağının mikrobiyal topluluğu, arılara özgü olan ve bireyler arasındaki sosyal etkileşimler yoluyla bulaşan dokuz bakteri türüne sahiptir ve memeli mikrobiyotasından çok daha basit yapıdadır. Bu mikrobiatadan beş tanesi (Snodgrassella alvi, Gilliamella apicola, iki tür Lactobacillus, ve Bifidobacterium) dünya çapında her ergin işçi arıda bulunmakta ayrıca bombus arılarında da tanımlanmıştır. Diğer dört tür (Bartonella apis, Apibacter adventoris, Frischella perrara ve Acetobacteraceae) birçok işçi arıda tanımlanmış ancak hepsinde bulunmamaktadır. Bu simbiyotik mikroorganizmalar, vitamin üretimine katkı sağladıkları gibi besinlerle alınan karbonhidratların metabolize edilmesine yardımcı olarak patojen mikroorganizmalara karşı doğal koruma sağlamaktadırlar. Bu mikrobiyota topluluğunun metabolizmada, bağışıklık sisteminde, büyüme ve gelişmede ayrıca hastalık ve zararlılara karşı korunmada rol oynadıkları bildirilmektedir (Martinson ve ark., 2012; Kwong ve ark., 2016; Raymann ve ark., 2018). Deneysel sonuçlar; bağırsak bakterilerinin genç işçi arılarda kilo alımını arttırdığını, insülin ve vitellogenin seviyelerini düzenleyen genlerin ekspresyonunu etkilediğini ve sukroz duyarlılığını arttırdığını göstermektedir. Bu mikrobiyota ayrıca, bağırsak içindeki fiziko kimyasal koşulları da düzenleyerek $\mathrm{pH}$ ve oksijen seviyelerini düşürür. Bağırsak bakterileri, insan ve diğer hayvanların bağırsaklarında olduğu gibi, ana metabolitler olarak asetat ve propiyonat içeren kısa zincirli yağ asitleri üretmektedirler (Zheng ve ark., 2017). Genom bazlı deneysel araştırmalar, G. apicola suşlarının, konakçı tarafından başka şekilde sindirilemeyen kompleks karbonhidratları (yani, polen hücre duvarından pektini) potansiyel olarak sindirdiğini ancak bu aktivitenin bu türün suşlarının bir alt kümesi ile sınırlı olduğunu göstermiştir (Engel ve ark., 2012). Koloni için büyük öneme sahip ana arı bağırsak mikrobiyotasının farklı işçi arı kompoziyonunda, farklı çevre ve koloni şartlarında, aynı zamanda ana arı yaşlandıkça çarpıcı bir değişim gösterdiği belirlenmiştir. Ana arının erken yaşam evresinde mikrobiyota topluluğu baskın olarak enterik bakterilerden, fakat yaşlandıkça alfaproteobakterilerden oluşmaktadır (Tarpy ve ark., 2015).

\section{Sindirim Enzimleri}

Sindirim enzimleri, biyopolimerleri, su molekülleri ile bölen hidrolazlardır. Bunlar esas olarak mide epiteli tarafından salgılanan farklı tipte sindirim enzimleridir (örneğin; proteazlar, karbonhidrazlar, lipazlar). Karbonhidrazlar, mide epiteli yanı sıra tükrük bezlerinden de salgılanmaktadır. Bir böcek yediği besine bağlı olarak sadece birkaç farklı karbonhidrat için enzime sahiptir. Bal arıları, nektarda temel karbonhidrat olarak bulunan sakkarozu hızı ı bir şekilde dönüştüren a-glukosidaz ya da sukraz enzimine sahiptir. Elde edilen glukoz ve fruktozu hem acil enerji ihtiyacı hem de bal yapımı için kullanabilmektedirler. Böceklerin yediği çoğu yağların içinde triasilgliseroller bulunmakta, lipazlar bağırsaktan salgılanmakta, triasilgliserollerden yağ asitleri ve glisereolleri dönüştürmektedir. Proteinazlar ise serin, sistin, aspartik asit ve metalloproteinaz olmak üzere enzimin aktif bölgesinde bulunan amino asit ya da metale bağlı olarak sınıflandırılmaktadır. Enzimler ayrıca amino asitlere etki eden özel inhibitörlere duyarlılıkları, sadece belirli tip proteinazlara özel olmalarına ve optimum aktive için uygun $\mathrm{pH}$ değerlerine bağlı olarak da sınıflandırılabilirler. Bazı proteinazlar asit, bazıları ise alkali $\mathrm{pH}$ ortamında aktivite gösterebilmektedir (Nation, 2015). Arılar tarafından tüketilen kompleks besinler, son asimilasyon ve kullanım için bağırsak duvarından hemolimfe emilmeden önce sindirim enzimlerinin aktivitesine bağlı olarak daha basit birimlere sindirilmektedir. Tükürük, postserebral ve hipofarenks bezlerinin salgısında ve barsak epitel hücrelerinin salgısında enzimler bulunmaktadır. Proteini sindiren enzimler ergin arının sindirim kanalında bol miktarda bulunur ve neredeyse tamamen mide ve hipofarenks bezleri tarafından salgılanmaktadır. Proteinler önce peptonlara ve polipeptitlere ayrılır ve bunlar da, amino asitlere hidrolize edilir. Lipaz; ergin işçi ve erkek arıların orta bağırsak kesiminde bol miktarda bulunur. Daha yüksek hayvanlarda lipitler, lipaz veya esterazlar tarafından serbest yağ asitleri ve gliserole sindirilmektedir. Yağ asitleri sindirim kanalında 
alkalilerle nötrleştirilerek suda çözünür hale getirilmektedir (Standifer ve ark., 1977).

Bal arılarında ağız ve ağız parçalarına sekresyon yapan dört çift salgı bezi bulunmaktadır. Bunlardan labial ya da tükrük bezleri ve toraks kökenli tükrük bezleri olarak adlandırılan bezler besinlerin sindiriminde rol oynamaktadır. Bu her iki bez de ortak bir kanal ile ağıza salgı yapmakta temel olarak şekerlerin çözülmesinde, çiğnenmesi gereken materyallerin yumuşatılmasında ve ana arının temizlenmesinde işlev göstermektedir. Bal arılarındaki toraks kökenli tükrük bezleri diğer böceklerdeki temel tükrük bezlerine karşılık gelmektedir ki bu bezlerden larva döneminde ipek salgılanmaktadır. Toraks kökenli salgı bezlerinin şekerleri çözebilen daha sulu, labial bezlerin ise daha yağlı bir sekresyonu vardır. Arı sütü salgılanmasından sorumlu olan hipofarenjeal bezlerden de nektarın bala dönüştürülmesinde görev alan invertaz enzimi salgılanmaktadır. Toraks ve labial tükrük bezlerinin büyüklüklük ve işlevinin işçi arı yaşı ile ilgisi olmadığı halde hipofarenjeal bezlerin işlevi ve büyüklüğü işçi arı yaşı ile bağlantılıdır, yavru besini üreten bu bezin tam gelişimi ve salgı üretimi protein tüketimi ile doğrudan ilişkilidir (Snodgrass, 1910; Winston, 1987).

Hipofarenjeal bezin gelişimi ve fizyolojik aktivitesi, işçi arının yaşı ve görevine göre değişmektedir. İşçi arılarda özellikle 15. günden sonra nektarın bala dönüştürülmesinde kullanılan enzimleri ürettiği belirlenmiştir. Bu enzimler; invertaz, a-glukosidaz, amilaz, glukosidaz oksidaz, galaktosidaz, esteraz, lipaz, lösin arilamidaz gibi enzimlerdir. Invertaz; sukrozun baldaki ana şekerler olan fruktoza ve glikoza dönüştürülmesinden sorumlu olduğu, glukonik asit; balı asidik tutarak hidrojen peroksit ile birlikte antiseptik bir etkiye oluşturduğu, glukoz oksidazın; glikozu glukonik asit ve hidrojen peroksite dönüştürdüğü bildirilmiştir. Amilazın ise nektarda bulunan bitkisel kökenli nişastayı glikoza dönüştürmek için gerekli olduğu düşünülmektedir (White ve ark., 1963; Simpson ve ark., 1968; Winston, 1987; Ohashi ve ark., 1999; Deseyn ve Billen, 2005).

Bal arısı genomunda; karbonhidrat metabolize edici enzimleri kodlayan (174 adet) ve lipit metabolize edici enzimleri kodlayan (28 adet) genler belirlenmiştir. Özellikle, glikolitik enzimleri, selülaz, glukoz oksidaz ve glikoz dehidrojenazları, glukozemettanol-kolin (GMC) oksidoredüktazları, fukosiltransferazları ve lizozimleri kodlayan genler için gen sayısında veya genomik organizasyonda çarpıcı değişiklikler tespit edilmiştir. Yağ asidi sentezi ve metabolizması, keton sentezi ve yıkımı, glikoliz/glukoneogenez için metabolik yollar ve karbonhidrat metabolizması ile ilişkileri detaylı olarak açıklanmıştır (Kunieda ve ark., 2006).

\section{TEMEL BESIN GEREKSINIMLERI}

Bal arılarının temel besin maddesi ihtiyaçları bireysel ve koloni bazında değerlendirilmektedir. Bu besin gereksinimleri cinsiyete, gelişme dönemine, özellikle ergin işçi arı yaş gruplarına, ana arı ve erkek arılarda üreme fonksiyonlarına ve mevsime göre bazı farklılar göstermektedir. Bal arılarının karbonhidrat kaynağı nektar veya salgılardan sağlanırken protein kaynağı polen, arı ekmeğidir. Nektardan dönüştürülen bal, polenden arı ekmeği ve bunları tüketerek üretilen arı sütü, bileşiminde bal arılarının gereksinim duyduğu karbonhidrat ve proteinlerin yanı sıra vitaminler, mineraller, amino asitler ve yağları içermektedir. Koloninin su ihtiyacı temelde nektardan sağlansa da, gereksinim halinde tarlacı arılar tarafından su da kovana taşınmaktadır.

Tüm canlılar gibi, bal arıları da hayatta kalmak için suya ihtiyaç duyarlar. Su, sadece ergin arılarda ozmotik dengeyi sağlamak için değil, aynı zamanda yavru için sıvı yiyecek hazırlamak ve kovanı sıcak günlerde serinletmek için de gereklidir. Bir bal arısı kolonisinde tarlacılar tarafından su toplama gereksinimi, yüksek sıcaklıklar kovanın içerisini buharlaşma ile soğutmayı gerekli kıldığı zaman artmakta, aşırı ısınma tehlikesi geçtiğinde azalmaktadır. Bireysel farklılıklar olsa da bal arılarının özellikle sodyum içeren tuzlu su kaynaklarını tercih ettikleri bildirilmiştir (Winston, 1987; Kuhnholz ve Seeley, 1997; Lau ve Nieh, 2016).

\section{Karbonhidratlar}

Balmumu salgılama ve petek örme, kovan içi temizliği, diğer yavru ve ergin arıların beslenmesi, kovan içi ve yavru alanı sıcaklığının ayarlanması, polen ve nektar toplayan tarlacıların uçuşu ve diğer kovan içi-dışı faaliyetler için gerekli enerji karbonhidratlardan sağlanmaktadır.

Enerji ihtiyacını karşılayan karbonhidratlar; nektarın bileşiminde bulunan bir disakkarit olan sukroz ve bunun monosakkarit bileşenleri olan glukoz ve fruktoztan kaynaklanmaktadır. Nektarın toplandığı bitki türlerine göre bu şekerlerlerin oranı \%10-70 arasında farklılık göstermektedir (Nicolson ve Thornburg, 2007). Bir çiçek nektarının enerji içeriği, hacmine ve şeker konsantrasyonuna bağlıdır. Arılar nektar konsantrasyonundaki küçük farklılıkları ayırt edebilir ve yüksek konsantrasyonlu olanları tercih etmektedir (Roubik ve Buchmann 1984; Corbet, 2003; Nicolson, 2011). Ergin arılar glukoz, fruktoz, sukroz, 
trehaloz, maltoz ve melezitoz gibi karbonhidratlardan yararlanırken, ramnoz, ksiloz, arabinoz, galaktoz, mannoz, laktoz, rafinoz, melibioz, stakiyoz, dekstrin, insülini kullanamazlar ve bazıları toksik etki gösteren karbonhidratlardır (Barker ve Lehner, 1976; Barker, 1977; Standifer ve ark., 1977).

Nektar; içeriğinde şekerler ile birlikte su ve özellikle bala kendine has aromasını veren diğer bazı maddeleri de içermektedir. Nektarın su içeriği kaynağına ve çevresel koşullara göre farklılıklar göstermektedir. Amino asitler özellikle böceklerle tozlanan bitki nektarlarında daha az konsantrasyonlarda olmalarına rağmen, şekerlerden sonra nektar bileşiminde en bol bulunan diğer maddeler arasındadır. Nektarda bulunan prolin miktarının bal arılarını cezbedici özelliği olduğu, benzer şekilde glisinin de cezbedici ve bal arısı öğrenme yeteneğini geliştirdiği belirtilmiştir. Prolin balda kalite kriteri olarak da değerlendirilmektedir. Nektar bileşiminde bulunan diğer maddeler; organik asitler, terpenler, alkoloidler, flavonoidler, glikositler, vitaminler, fenolikler ve yağlar olduğu çeşitli araştırmacılar tarafından bildirilmiştir (Roubik ve Buchmann 1984; Gardener ve Gillman 2001; Carter ve ark., 2006; Nicolson, 2011).

İşçi arılar bal midelerini nektarla doldurup kovana geri döndüklerinde, nektar ya bu arılar tarafından ya da kovan içerisindeki diğer arılar tarafından ağızdan alınarak petek gözlerine depolanmaktadır (Snodgrass, 1910; Winston, 1987). Nektarın bala dönüşüm süreci tarlacı işçi arıların bal midesinde başlatılmakta, invertaz, diastaz, glukoz oksidaz enzimleri eklenerek olgunlaştırma sürecinde nem içeriği \%16-20 arasına düşürülmektedir. Sosyal organizasyonları gereği bakıcı işçi arılar kolonideki diğer tüm bireylerin beslenmesinden sorumludur. Bakıcı işçi arılar da yavru besini olan arı sütünü üretmek için polen ve bal tüketmek zorundadır (Kunert ve Crailsheim, 1988). Bir işçi arı larvası 5 günlük beslenme döneminden sonra ortalama olarak $150 \mathrm{mg}$, erkek arı larvaları ise 6.5 gün beslenme dönemi sonunda 340 mg ağırlığa ulaşmaktadır (Jay, 1963). Bir işçi arı yetiştirmek için toplam karbonhidrat miktarının kabaca 59.4 mg ve bir erkek arı için $98.2 \mathrm{mg}$ olduğu tahmin edilmektedir (Rortais ve ark., 2005). Ergin bir bal arısı, hayatta kalmak için günde yaklaşık $4 \mathrm{mg}$ kullanılabilir şekere intiyaç duymaktadır (Barker ve Lehner, 1974). Her bir saatlik uçuş için polen ve nektar toplayan tarlacı işçi arıların yaklaşık 8-12 mg şekere gereksinim duydukları bildirilmiştir (Balderrama ve ark., 1992). Bir bal arısı kolonisinin yıllık bal gereksiniminin yaklaşık 60-80 kg civarında olduğu bildirilmiştir (Seeley, 1985; Winston, 1987). Bal hasatından sonra ek besleme yapılmayan kolonilerde, kış mevsiminden kalan depolar tükendiği zaman ve nektar kaynakları zayıf olduğunda ilkbaharda karbonhidrat eksikliği ortaya çıkarsa yetiştirilen larva sayısı da sınırlandırılmaktadır (Brodschneider ve Crailsheim, 2010).

\section{Proteinler}

Çiçekli bitkilerin erkek gametofiti olan polen, arıların temel protein kaynağı olmakla birlikte mikrobesinlerin de kaynağıdır. Polen kimyasal bileşimi bakımından proteinler, lipitler, şekerler, lifler, mineral tuzlar, amino asitler, fenolik bileşikler ve vitaminlerden oluşur. Yüksek konsantrasyonda indirgenmiş şekerler, esansiyel amino asitler ve doymamış/doymuş yağ asitleri, Zn, Cu, Fe ve yüksek K/Na oranının bulunması bal arısı polenini insan diyetleri için de önemli kılmaktadır. Polenin ana bileşenleri; oranı \%13-55 arasında değişmekle birlikte karbonhidratlar (fruktoz, glukoz, sakkaroz), \%10-40 arasında proteinler (amino asitler, enzimler), \%0.3-20 arasında ham lifler ve \%1-10 lipidlerdir (yağ asitleri, steroller, hidrokarbonlar) (Campos ve ark., 2008; Bogdanov, 2017).

Bal arıları; gelişim için on amino asite gereksinim duymaktadır: arginin, histidin, lisin, triptotan, fenilalanin, metiyonin, treonin, lösin, izolösin ve valin (De Groot, 1953). Polenin protein ve amino asit içeriği botanik kökene bağlı olmakla birlikte esansiyel amino asit konsantrasyonu botanik orijine bağlı olmaksızın stabil olduğu; özellikle glutamik asit, aspartik asit, prolin, lösin, lisin, arjinin ve serin amino asitlerinin çeşitli araştırmacılar tarafından polen içeriğinde bol miktarda bulunduğu bildirilmiştir (Szczęsna, 2006). Çiçeklerden elle toplanan, polen tuzaklarından ve petek gözlerinden (arı ekmeği) elde edilen polenlerin kimyasal bileşimi farklılık göstermektedir. Elle toplanan 377 polen türünde protein seviyesinin kuru ağırlığın \%2-60'ı gibi geniş bir aralıkta değiştiği belirlenmiştir (Roulston ve ark., 2000).

Çiçeklerden tarlacı işçi arılar tarafından toplanan farklı boyut yüzey şekillerine sahip polenler, bir miktar nektar ile nemlendirilerek arka bacaklarında bulunan polen sepetçiklerinde koloniye taşınır. Kovan içerisinde daha fazla nektar, tükrük salgısı ve mikrobiyal içerik eklenen polen genellikle yavru alanına yakın gözlere depolanır ve besin değeri daha yüksek olan arı ekmeği şeklinde tüketilir (Herbert ve Shimanuki, 1978; Thorp, 1979; Winston, 1987).

İşçi arıların polen tüketimi ve gereksinimi yaşına ve koloni içerisindeki görevine bağlı olarak değişmektedir. Kolonide polenlerin tüketimi ve metabolize edilmesi tüm arılar arasında eşit derecede gerçekleşmemektedir. Özellikle 8 günlük bakıcı işçi arılar, diğer bireyler arasında midelerinde en yüksek 
proteolitik aktiviteye sahip olmaları nedeniyle koloninin birincil polen işleyici ve dağıtıcısı konumundadırlar. Bakıcı işçi arılar, yaşamlarının ilk 810 günü boyunca, hipofarenjeal ve mandibular bezlerini geliştirmek ve larva besinlerini üretmek için polen tüketmelidirler. Bununla birlikte polen toplayıcı tarlacı arılar çok az polen tüketir, polenleri sindirmek için daha az enzimatik yeteneğe sahiptir ve hipofarenjeal bezleri atrofiye olmuştur. Proteince zengin arı sütü sadece yavruları beslemek için değil aynı zamanda ergin bireyler içerisinde özellikle ana arıyı beslemek üzere üretilmektedir. On çerçeveli bir bal arısı kolonisinin polen gereksinimi $17.8 \mathrm{~kg}$ olarak bildirilmiştir. Balın aksine polen daha az miktarlarda depolanmakta, tarlacılık faaliyetinin olmadığı zamanlarda depolar daha hızlı tüketilmektedir. Larvalar özellikle proteine bağımlıdır ve yavru üretimi protein yetersizliğinden güçlü bir şekilde etkilenmekte, kanibalizm (yavru yeme) davranışı görülebilmektedir. Larvalı gözlerin ortalama sırlanma zamanı ile polen gelişi arasında önemli bir ilişki bulunmakta; larvaların gelişimi sırasında kovanda ne kadar az polen depolanmış ise larvalı gözler o kadar erken sırlanmaktadır (Crailsheim, 1990; Crailsheim ve ark., 1992; Hrassnigg ve Crailsheim, 1998; Schmickl ve Crailsheim, 2001; Schmickl ve Crailsheim, 2002).

Arıların nektarda olduğu gibi polen kalitesini değerlendirebileceği ve protein seviyesi yüksek olan polenleri seçebileceğine dair çok az kanıt vardır. Bal arılarının polen rezervlerinin miktar veya kalitesindeki eksikliklere karşı yanıtı, daha çok protein içeriğine sahip polen toplama konusunda uzmanlaşmak yerine, kovana getirilen brüt polen miktarını artırmak olmuştur (Pernal ve Currie, 2001). Farklı boyut ve şekildeki polenlere nektar eklenmesi işçi arı polen sepetçiklerinde kovana taşınmasını kolaylaştırmaktadır. Arı ekmeği koloninin hayatta kalabilmesi ve özellikle erken ilkbaharda populasyon gelişimi için büyük öneme sahiptir (Herbert ve Shimanuki, 1978; Thorp, 1979; Vasquez ve Olofsson, 2009; Brodschneider ve Crailsheim, 2010). Koloni nüfus artışı ve işçi arı kalitesi, diyet bileşiminden önemli ölçüde etkilenmektedir. Bal arısı beslenmesinde en uygun diyet proteini konsantrasyonunu belirlemek için yapılan bir saha çalışması sonuçlarına göre, erken ilkbaharda bal arıları diyetinde \%29.5-34.0 ham protein içeriği önerilmiştir. Diyet içeriğinde yüksek protein oranı tersine etki göstererek ömür uzunluğunu kısaltarak, nüfus artışını azaltmıştır (Zheng ve ark., 2014).

Koloninin diğer protein kaynağı olan arı sütü bileşimi \%60-70 su, \%9-18 proteinler, \%7-18 karbonhidratlar, \%3-8 lipitler, esansiyel amino asitler, vitaminler ve minerallerden oluşur. Bununla birlikte, arı sütü bileşiminde niasin (B3 vitamini), pirioksidin (B6), tiamin (B1), riboflavin (B2), pantotenik asit, folik asit, biotin yanı sıra magnezyum, potasyum, kalsiyum, çinko, demir ve bakır minerallerini, az miktarda polifenol bileşikler içermektedir (Sabatini ve ark., 2009; Ramadan ve Al-Ghamdi, 2012; Bogdanov, 2017). Bal arıları, sosyal böcekler arasında bile eşsizdir, çünkü sadece kaliteli ve bol miktarda arı sütü ile beslenen dişi larvalar ana arı olarak yetiştirilebilmektedir. Ana arı olarak yetiştirilecek larvalar ilk üç gün yoğun olarak mandibular bez salgılarıla daha sonra hem mandibular hem de hipofarenjeal bezi salgıları karışımıyla beslenmektedir. İşçi arı larvaları, larva döneminin ilk birkaç günü hipofarenjeal bez salgılarıyla beslendikten sonra kalan günlerde arı sütü, bal ve polen karışımı ile beslenmektedirler. Larvanın ilk besini (ilk 3.5 gün) proteince zengin iken son besini karbonhidratlarca zengindir. Ergin çıkıştan sonra işçi arılar yavru alanı etrafındaki bal ve polenli gözlerden, ayrıca diğer işçi arılardan ağız parçaları yoluyla (trophallaxis) beslenmektedirler. Erkek arı larvalarına ise daha düşük kalitede protein, gelişim süresinin uzun olmasından ve vücut büyüklüğünden dolayı daha çok miktarda besin verilmektedir (Brouwers ve ark., 1987; Winston 1987; Kunert ve Crailsheim, 1987).

Bal arısı feromonlarının beslenme ve besin toplama üzerindeki etkileri de unutulmamalıdır. Hem ana arılar hem de yavrular, kooperatif yavru bakımını güçlü bir şekilde etkileyen primer feromonlar üretmektedir. Kendi kendini besleyemeyen bal arısı larvaları feromonlar yayarak, bakıcı işçi arıların davranışlarını ve fizyolojilerini etkiler, onları uygun beslenme kaynakları sağlamaları için teşvik eder, daha çok polen toplamayı uyarır. (Pankiw ve ark., 1998; Le Conte ve ark., 2001; Sagili ve Pankiw, 2009).

\section{SONUÇ}

Bal arıları; herbivor, tam metamorfoz geçiren, sosyal bir organizasyon kapsamında koloniler halinde yaşayan ekonomik ve ekolojik öneme sahip böcekler olup nektar, salgı balları, polen, arı sütü ve su gibi insanlar tarafından da tüketilebilen besinlerle beslenmektedirler. Kolonide, önce protein ağırlıklı olan beslenme daha sonra karbonhidrat ağırlıklı olarak fizyolojik gelişim dönemlerine göre uyarlanmaktadır. Polen ve nektar toplama yani tarlacılık faaliyetleri, ana arı ve işçi arıların genetik yapısı, koloni populasyonunun büyüklüğü ve demografik yapısı ve diğer çevresel faktörlere (mevsim, sıcaklık, yağış, flora vb) göre belirlenmektedir. Ek ve destek besleme 
uygulamaları yapılsa da bal arılarının beslenmesi tamamen floraya bağlıdır bu nedenle besin kaynaklarının kalitesi, miktarı ve tarımsal ilaçlardan ne kadar ari olduğu kolonilerin devamlılığı ve sağlığı açısından büyük önem taşımaktadır. Sağlıklı ve güçlü koloniler hastalık ve zararlılarla daha iyi mücadele eder, doğal kaynakları daha iyi kullanır ve arıcılıktan elde edilen ürün miktarını artırmanın yanı sıra polinasyona yaptıkları katkı ile bitkisel üretimde de kalite ve miktar artışına katkı sağlar.

Bal arıları, dünya tarımında tozlayıcı olarak önemli bir rol oynamaktadır, ancak popülasyonları son otuz yılda parazitler ve patojenler, böcek ilaçlarına maruz kalma, yetersiz ve kalitesiz diyetlerle beslenme nedeniyle tehdit altındadır. Habitat dönüşümü ve kaybı nedeniyle oluşan beslenme stresinin, arı popülasyonlarındaki kayıplara katkıda bulunan ana faktörler arasında olduğu düşünülmektedir (Wright ve ark., 2018). Özellikle monokültür tarımda verimlilik için kimyasal mücadelenin yoğun yapıldığı alanlarda doğal tozlayıcı böcek populasyonlarının giderek azalması, verim ve ürün kalitesi için bitkisel üretimde bal arısı kullanımı konusunda farkındalık yaratılması gerekmektedir (Topal ve ark., 2017).

Yeterli beslenme, sağlıklı bal arısı kolonilerinin gelişimini destekler (Brodschneider ve Crailsheim, 2010). Koloninin beslenme durumu ile sosyal ve

\section{KAYNAKLAR}

Alaux C, Dantec C, Parrinello H, Le Conte Y. 2011. Nutrigenomics in honey bees: digital gene expression analysis of pollen's nutritive effects on healthy and varroa-parasitized bees. BMC Genomics, 12:496.

Balderrama NM, Almeida LO, Núñez JA. 1992. Metabolic rate during foraging in the honeybee. Journal of Comparative Physiology B 162: 440-447.

Barker R J, Lehner Y. 1974. Acceptance and sustenance value of naturally occurring sugars fed to newly emerged adult workers of honey bees (Apis mellifera L.). Journal of Experimental Zoology 187: 277-285.

Barker RJ, Lehner Y. 1976. Galactose a sugar toxic to honey bees found in exudate of tulip flowers. Apidologie 7: 109-112.

Barker RJ. 1977. Some carbohydrates found in pollen and pollen substitutes are toxic to honey bees. Journal of Nutrition 107: 1859. 1862.

Bogdanov S. 2017. Pollen: production, nutrition and health: a review. Bee Product Science. Available: http: //www.beehexagon.net/(23.01.2019).

Bogdanov S. 2017. Royal jelly, bee brood: composition, nutrition, health. The Royal Jelly Book, Chapter 2. Bee Product Science, Available: http: //www.bee-hexagon.net/ (23.01.2019).

Brodschneider R, Crailsheim K. 2010. Nutrition and health in honey bees. Apidologie 41: 278-294.

Brouwers EVM, Ebert R, Beetsma J. 1987. Behavioural and physiological aspects of nurse bees in relation to the composition of larval food during caste differentiation in the honeybee. Journal of Apicultural Research 26: 11-23.

Campos MGR, Bogdanov S, Almeida-Muradian LB, Szczesna B, Mancebo Y, Frigerio C, Ferreira F. 2008. Pollen composition and bireysel bağışıklık sisteminin etkinliği arasında bir ilişski bulunmaktadır. Örneğin parazitik varroa akarları besin seviyesini (protein metabolizmasını inhibe ederek) azaltırlar, bireysel bağışıklık fonksiyonunu baskılar ve virüsleri iletirler. Polen, antimikrobiyal peptit (AMP) bileşenlerini de içeren peptidlerin bağışıklık sisteminde sentezi için gerekli esansiyel amino asitleri sağlayarak metabolik yolları aktive eder, uzun ömürlülüğü etkiler (Alaux ve ark., 2011; DeGrandiHoffman ve Chen, 2015). Bununla birlikte arıcılık ürünlerinin apiterapi ile insan sağlığında koruyucu ve destek tedaviler için kullanımı yaygındır (Topal ve ark., 2018). Insanlar için de sağlıklı arıcılık ürünleri üretebilmek, bal arılarının sağlığı dolayısı ile beslenme kaliteleriyle yakından ilişkilidir.

Her koloninin kendine has demografik yapısı nedeniyle besin ihtiyaçları ve beslenme düzeyi, yetiştiricilik yapılan ekolojik ve iklim koşullarına göre farklılık göstermektedir. Bu derlemede, koloniyi oluşturan bireylerin temel besin gereksinimleri, sindirim sistemi anatomisi ve fizyolojisi özetlenmeye çalışılmıştır. Besin toplama tercih ve davranışları yanı sıra diğer bir önemli konu, destek beslemelerinde diyet kompozisyonun belirlenmesinde koloni ve bireysel düzeyde yapılmış detaylı çalışmaların ayrıca incelenmesi öngörülmektedir.

standardisation of analytical methods. Journal of Apicultural Research 47(2): 154-161.

Carter C, Shafir S,Yehonatan L, Palmer RG, Thornburg R. 2006. A novel role for proline in plant floral nectars. Naturwissenschaften 93: 72-79.

Corbet SA. 2003. Nectar sugar content: estimating standing crop and secretion rate in the field. Apidologie 34: 1-10.

Crailsheim K, Schneider LHW, Hrassnigg N, Bühlmann G, Brosch U, Gmeinbauer R, Schöffmann B. 1992. Pollen consumption and utilization in worker honeybees (Apis mellifera carnica): dependence on individual age and function. Journal of Insect Physiology 38: 409-419.

Crailsheim K. 1990. The protein balance of the honey bee worker. Apidologie 21: 417-429.

Crailsheim K. 1992. The flow of jelly within a honeybee colony. Journal of Comparative Physiology B 162: 681-689.

Dade HA. 1962. Anatomy and dissection of the honeybee. International Bee Research Association\&Northern Bee Books. 2017. $196 \mathrm{p}$.

DeGrandi-Hoffman G, Chen Y. 2015. Nutrition, immunity and viral infections in honey bees. Current Opinion in Insect Science 10: $170-176$.

De Groot AP. 1953. Protein and amino acid requirements of the honeybee (Apis mellifica L.). Physiologia Comparata et Oecologia 3: $197-285$.

Deseyn J, Billen J. 2005. Age-dependent morphology and ultrastructure of the hypopharyngeal gland of Apis mellifera workers (Hymenoptera, Apidae). Apidologie 36(1): 49-57.

Engel P, Martinson VG, Moran NA. 2012. Functional diversity within the simple gut microbiota of the honey bee. Proceedings National Academy of Sciences of the USA 109:11002-11007. 
Gardener MC, Gillman MP. 2001. Analyzing variability in nectar amino acids: composition is less variable than concentration. Journal of Chemical Ecology 27: 2545-2558.

Haunerland NH, Shirk PD. 1995. Regional and functional differentiation in the insect fat body. Annual Review of Entomology 40: 121-145.

Herbert EW, Shimanuki H. 1978. Chemical composition and nutritive value of bee-collected and bee-stored pollen. Apidologie 9: 33-40.

Hrassnigg N, Crailsheim K. 1998. The influence of brood on the pollen consumption of worker bees (Apis mellifera L.). J. Insect Physiology 44: 393-404.

Jay SC. 1963. The development of honeybees in their cells. Journal of Apicultural Research 2: 117-134.

Kuhnholz S, Seeley TD. 1997. The control of water collection in honey bee colonies. Behavioral Ecology and Sociobiology 41: 407-422.

Kunert K, Crailsheim K. 1988. Seasonal changes in carbohydrate, lipid and protein content in emerging worker honeybees and their mortality. Journal of Apicultural Research 27: 13-21.

Kunieda T, Fujiyuki T, Kucharski R, Foret S, Ament SA, Toth AL, Ohashi K, Takeuchi H, Kamikouchi A, Kage E, Morioka M, Beye M, Kubo T, Robinson GE, Maleszka R. 2006. Carbohydrate metabolism genes and pathways in insects: insights from the honey bee genome. Insect Molecular Biology 15(5): 563-576.

Kwong WK, Moran NA. 2016. Gut microbial communities of social bees. Nature Reviews Microbiology 14:374-384.

Lau PW, Nieh JC. 2016. Salt preferences of honey bee water foragers. Journal of Experimental Biology 219:790-6.

Le Conte Y, Mohammedi A, Robinson GE. 2001. Primer effects of a brood pheromone on honeybee behavioural development. Proceedings of the Royal Society B 268:163-168.

Martinson VG, Moy J, Moran NA. 2012. Establishment of characteristic gut bacteria during development of the honeybee worker. Applied and Environmental Microbiology 78:2830-2840.

Nation JL. 2015. Insect physiology and biochemistry. CRC Press.Taylor\& Francis Group. 690 p.

Nicolson SW, Thornburg RW. 2007. Nectar chemistry. In nectar and nectaries. ed. SW Nicolson, M Nepi, E Pacini. Dordrecht, Neth. Springer.

Nicolson SW. 2011. Bee food: the chemistry and nutritional value of nectar, pollen and mixtures of the two. African Zoology 46(2): 197-204.

O’Toole C, Raw A. 1991. Bees of the world. London: Blanford, 192 p.

Ohashi K, Natori S, Kubo T. 1999. Expression of amylase and glucose oxidase in the hypopharyngeal gland with an age dependent role change of the worker honeybee (Apis mellifera L.). European Journal of Biochemistry 265: 127-133.

Pankiw T, Page RE Jr, Fondrk MK. 1998. Brood pheromone stimulates pollen foraging in honey bees (Apis mellifera). Behavioral Ecology and Sociobiology 44:193-198.

Pernal SF, Currie RW. 2001. The influence of pollen quality on foraging behavior in honeybees (Apis mellifera L.). Behavioral Ecology and Sociobiology 51:53-68.

Ramadan M, Al-Ghamdi A. 2012. Bioactive compounds and health promoting properties of royal jelly: A review. Journal of Functional Foods 4: 39-52.

Raymann K, Moran NA. 2018. The role of the gut microbiome in health and disease of adult honey bee workers. Current Opinion in Insect Science 26: 97-104.

Robinson GE, Page RE. 1989. Genetic determination of nectar foraging, pollen foraging, and nest-site scouting in honey bee colonies. Behavioral Ecology and Sociobiology 24:317-323.

Rortais A, Arnold G, Halm MP, Touffet-Briens F. 2005. Modes of honeybees exposure to systemic insecticides: estimated amounts of contaminated pollen and nectar consumed by different categories of bees. Apidologie 36: 71-83.

Roubik DW, Buchmann SL 1984. Nectar selection by Melipona and Apis mellifera (Hymenoptera: Apidae) and the ecology of nectar intake by bee colonies in a tropical forest. Oecologia 61: 1-10.
Roulston TH, Cane JH. 2000. Pollen nutritional content and digestibility for animals. Plant Systematics and Evolution 222: $187-209$.

Sabatini AG, Marcazzan G, Caboni MF, Bogdanov S, AlmeidaMuradian L.B. 2009. Quality and standardisation of royal jelly. Journal of ApiProduct and ApiMedical Science, 1:1-6.

Sagili RR, Pankiw T. 2009. Effects of brood pheromone modulated brood rearing behaviors on honey bee (Apis mellifera L.) colony growth. Journal of Insect Behavior 22:339-349.

Schmickl T, Crailsheim K, 2001. Cannibalism and early capping: strategy of honeybee colonies in times of experimental pollen shortages. The Journal of Comparative Physiology A 187: 541-547.

Schmickl T, Crailsheim K. 2002. How honeybees (Apis mellifera L.) change their broodcare behavior in response to non-foraging conditions and poor pollen conditions. Behavioral Ecology and Sociobiology 51: 415-425.

Schmickl T, Crailsheim K. 2004. Inner nest homeostasis in a changing environment with special emphasis on honey bee brood nursing and pollen supply. Apidologie 35: 249-263.

Seeley TD. 1985. Honeybee ecology, A study of adaptation in social life, Princeton University Press, Princeton. 214 p.

Seeley TD.1989. The honey bee colony as a superorganism. American Sciencist 77(6): 546-553.

Simpson J, Riedel IBM, Wilding M. 1968. Invertase in the hypopharyngeal glands of the honeybee. Journal of Apicultural Research 7: 29-36.

Snodgrass RE 1910. The Anatomy of the honey bee. Pickle Partners Publishing, 2018. 214 p.

Standifer LN, Moeller FE, Kauffeld NM, Herbert EW, Shimanuki H. 1977. Supplemental feeding of honey bee colonies. USDA Agriculture Information Bulletin No.413, 8 p.

Szczęsna T. 2006. Protein content and amino acid composition of beecollected pollen from selected botanical origins. Journal of Apicultural Science,50:81-90.

Tarpy DF, Mattila HR, Newton ILG. 2015. Development of the honey bee gut microbiome throughout the queen-rearing process. Applied and Environmental Microbiology 81:3182-3191.

Thorp RW. 1979. Structural, behavioral, and physiological adaptations of bees (Apoidea) for collecting pollen. Annals of the Missouri Botanical Garden 66: 788-812.

Topal E, Yücel B , Yıldızdal İ , Takma C , Aydın M , Karaca Ü . 2017. Kiraz Tozlașmasında Bal Arısı (Apis mellifera L.) ve Bombus Arısının (Bombus terrestris) Kimi Davranış Özelliklerinin ve Cevresel Sicaklık Değișiminin Bitki Fenolojisi ile Verim Üzerine Etkileri. Hayvansal Üretim, 58(2): 24-33.

Topal E, Strant M, Yücel B, Kösoğlu M, Mărgăoan R, Dayığlu M. 2018. Ana ve Erkek Arı Larvalarının Biyokimyasal Özellikleri ve Apiterapötik Kullanımı. Hayvansal Üretim 59 (2): 77-82.

Vásquez A, Olofsson TC. 2009. The lactic acid bacteria involved in the production of bee pollen and bee bread, Journal of Apicultural Research 48: 189-195.

White JWJr, Subers MH, Schepartz AI. 1963. The identification of inhibine, antibacterial factor in honey, as hydrogen peroxide, and its origin in a honey glucose oxidase system. Biochimica et Biophysica Acta 73, 57-70.

Winston ML. 1987. The biology of the honey bee. Harvard University Press, Cambridge, MA, USA. 281 p.

Wright GA, Nicolson SW, Shafir S. 2018. Nutritional physiology and ecology of honey Bees. Annual Review of Entomology 63:327-344.

Zheng B, Wu Z, Xu B. 2014. The effects of dietary protein levels on the population growth, performance, and physiology of honey bee workers during early spring. Journal of Insect Science 14:191.

Zheng H, Powell JE, Steele MI, Dietrich C, Moran NA. 2017. Honeybee gut microbiota promotes host weight gain via bacterial metabolism and hormonal signaling. Proceedings National Academy of Sciences of the USA 114:4775-4780. 